\title{
OECD/DAC 거버넌스 네트워크(GOVNET) 논의동향과 대응을 위한 정책과제
}

김은미, 김진경 이화여자대학교 국제대학원 교수, 국제개발협력연구원

\section{목차}

I. 서론

II. 거버넌스의 정의 및 개발과의 연계성에 관한 논의 동향

III. 거버넌스 네트워크(GOVNET)의 개요

IV. GOVNET의 정책 논의

V. 한국의 거버넌스 지원 ODA 현황

VI. 한국 거버넌스 지원에 대한 평가 및 정책 제언

\section{I. 서론}

세계 제 2 차 대전 이후 해외 개발원조가 본격적으로 유럽과 아프리카에 대거 투입되기 시작하면서 원조활동은 국제사회의 주요 이슈가 되어왔다. 그러나 서유럽의 성공적 전후 복구에 반해, 원조의 양적 증대에도 불구하고 사하라 이남 아프리카를 비롯한 많은 국가들의 빈곤이 사라지지 않자 공 여국들은 원조 효과성 문제를 제기하기 시작했다. 따라서 과거 원조의 양적 증가에만 초점을 맞추 었던 공여국들은 점차 원조 효과성과 원조의 질적 제고에 대한 활발한 연구와 논의를 하기 시작했 다. 원조 효과성에 대한 세계적 논의의 장으로 2002년 로마에서 열린 제 1차 원조효과성을 위한 고위급 회의가 개최되었고 그 이후 파리(2005년), 아크라(2008)를 거쳐 마지막 4차 회의가 2011 
년 한국에서 개최되게 되었다. 원조에 크게 힘입어 세계 13 위의 경제대국으로 발전한 한국에서 원 조효과성에 관한 최고위급 회담이 열리는 것은 큰 의미가 있다고 하겠다.

원조 효과성에 관한 논의와 함께, 국제사회는 이전의 경제적 접근만으로는 빈곤 문제를 해결할 수 없다는데 그 인식을 같이 하고 개발과 민주주의와 행정 시스템의 연계성에 주목하기 시작하였다 (UNDP 2003; Grindle 2007). 특히 1989년 발표된 World Bank의 보고서를 계기로 지속적인 경 제 개발 및 원조효과성 향상을 위해 굿 거버넌스(Good Governance)는 필수적 요소라는 주장이 개발협력분야에서 주류로 받아들여지기 시작하였다. 학계에서도 굿 거버넌스가 경제 성장에 미치 는 영향에 대한 연구를 활발히 진행해 왔으며 정부 정책, 정부의 효과성, 부정부패 등이 경제 성 장과 밀접한 관련이 있다는 것을 보여 주었다 (Burnside and Dollar 2000; Knack and Keefer 1995; Easterly et al 2004). 따라서 1990년대 후반부터 굿 거버넌스는 젠더, 환경과 함께 개발협 력 분야의 크로스커팅 이슈로서 빈곤 감소 및 천년개발목표(Millenium Development Goals, $\mathrm{MDGs}$ ) 달성을 위한 전제조건이자 주요 전략으로 간주되어 왔다.

거버넌스는 국가의 주요 정책들이 결정되고 정치, 경제, 행정 권력이 행사되는 절차 및 제도를 일 컫는다 (World Bank 1989; UNDP 1997). 굿 거버넌스에 대한 개념이 기관마다 조금씩 차이가 있 기는 하나 대부분 민주적인 거버넌스로 이해하고 있으며, 정부의 책임성, 투명성, 공정성, 효과성, 법의 존중을 주요 특징으로 제시한다 (World Bank 1989; UNDP 2003; OECD 1997; IMF 2005). 그러나 이와 같이 정치·경제·사회 전반에 걸쳐서 변화를 일으켜야 하는 굿 거버넌스는 많은 시간 과 비용이 소요되고 수원국의 굿 거버넌스 구축이라는 명목 하에 공여국이 수원국에 규제를 가하 거나 굿 거버넌스에 대한 공약을 수원국에 요구하는 등 외교적 문제를 야기할 수 있다는 비판이 제기되어 왔다. 또한 굿 거버넌스는 정치적 요소의 결합으로 인해 수원국의 정치적 자율성을 침해 한다는 논란도 제기되었다. 특히 World Bank와 International Monetary Fund (IMF)의 경우 수 원국의 거버넌스 향상에 대한 공약 및 이행 여부를 원조 제공을 위한 조건으로 삼고 있어 조건부 원조에 대한 비판적인 논의 역시 진행되어 왔다.

본 원고는 거버넌스와 개발의 연계성에 관한 국제적 논의의 동향을 살펴보고 이에 대한 대응으로 마련된 $\mathrm{OECD} / \mathrm{DAC}$ 산하 거버넌스 네트워크(GOVNET)의 역사 및 주요 활동 그리고 $\mathrm{OECD} / \mathrm{DAC}$ 의 거버넌스 관련 권고사항을 바탕으로 한국의 거버넌스 지원 현황을 분석-평가하고자 한다. 


\section{II. 거버넌스의 정의 및 개발과의 연계성에 관한 논의 동향}

\section{1. 거버넌스의 정의 및 배경}

거버넌스에 대한 논의는 1980 년대 말 신자유주의 정책에 대한 비판과 동시에 개발도상국의 공정 한 시장경제를 위한 제도적 기반 구축 및 투명성에 대한 요구와 함께 등장하였다. 특히 World Bank는 1989년 보고서에서 시장경제 체제는 굿 거버넌스가 충족되어야만 가능하다고 하였으며, 사하라이남 아프리카 국가들의 빈곤의 원인 중 하나로 거버넌스의 실패를 꼽았다. 또한 경제성장 과 민주주의의 발전의 연계성이 확인되면서 개발과 굿 거버넌스의 상관관계에 대한 중요성이 확산 되었다 (김은미 외 2010).

거버넌스의 정의에 대한 국제적 합의는 아직 이루어지지 않았으나 일반적으로 정치, 경제, 행정 등의 분야에 걸친 국가와 사회의 관계를 의미한다. World Bank는 1989년 정치적 권한 및 사회 경제적 개발을 위해 자원 운영에 대한 권한 행사를 거버넌스라고 칭하였으며, 굿 거버넌스는 효율 적인 행정 시스템, 신뢰할 수 있는 사법 시스템, 책임 있는 정권으로 정의하였다 (World Bank 1989). 또한 2009년에는 기존 정의에 권한을 행사하는 전통과 기관이라는 개념을 더하였다. 이는 정권이 선정, 감시, 교체되는 과정은 물론 정부가 효율적으로 건실한 정책을 마련하고 이행하는 역량 및 사회·경제적 행위를 통치하는 정부 기관에 대한 시민과 정부의 존중을 포함한다. World Bank는 위 정의에 기반을 두고 참여와 책임, 정치적 안정과 폭력의 부재, 정부 효과성, 규제의 질, 법치주의 그리고 부패 통제를 6개의 주요 거버넌스 지표로 선정했다 (World Bank 2009a).

World Bank가 주로 거버넌스의 경제적인 측면에 초점을 맞춘 반면, UN은 거버넌스의 민주·정치 적인 측면에 초점을 맞추고 있다. 따라서 UN은 굿 거버넌스를 통하여 부정부패를 줄이고, 의사결 정 과정에 국민이 적극적으로 참여하며, 결정에 대한 책임성이 보장되고, 이를 통해 시장경제가 원활히 운영될 수 있음을 강조한다 (UN 2007). 다시 말해 UN은 민주적 거버넌스를 굿 거버넌스 로 간주하며 다음의 8 가지 요소를 갖출 것을 권고하고 있다: 참여, 합의 지향, 책임성, 투명성, 대응성, 공정성과 포용성, 효과성 및 효율성, 그리고 법치주의를 포함한다. UN은 굿 거버넌스를 통하여 부정부패를 줄이고, 의사결정 과정에 국민이 적극적으로 참여하며, 결정에 대한 책임성이 보장되고, 이를 통해 시장경제가 원활히 운영될 수 있음을 강조한다 (UN 2007).

$\mathrm{OECD}$ 는 굿 거버넌스의 개념을 점차적으로 확대시켜 왔으며 그에 따라 권고사항도 수정·보완하였 다. $\mathrm{OECD}$ 는 거버넌스를 국정 운영에 필요한 정치적, 경제적, 행정적 권한의 집행으로 정의하며, 
정부의 합법성, 투명성, 책임성과 인권에 대한 존중을 굿 거버넌스의 주요 요소로 고려한다 $(\mathrm{OECD}$ 1997). 1995년 $\mathrm{OECD}$ 는 거버넌스를 구성하는 주요 요소로서 법치주의, 공공분야 운영, 부정부패 방지, 그리고 과다한 군사비 지출 감소 등을 꼽았다. 또한 굿 거버넌스의 강화를 위해 사회적 약 자를 위한 법적 지원과 권리 보호를 위한 시민사회 지원, 사법 시스템 개발 등 법치주의 강화, 여 성 및 사회 소수자의 참여 확대를 통한 차별 철폐 및 평등 도모를 위해 노력을 기울여 왔다 (OECD 1995). 1997년에는 법치주의, 회계, 예산, 그리고 공공지출 운영의 개선을 통한 공공 분야 운영, 그리고 투명성 및 책임성 강화와 부정부패의 척결을 굿 거버넌스의 주요 요소로 정의하였다 (NIDA 2004). 또한 민주적 거버넌스를 강조하며 인권 보호, 투명성, 책임성, 합법성, 참여, 평등을 주요 요건으로 제시하였다 (OECD 2007). 2010년 개발협력 보고서에서 $\mathrm{OECD}$ 는 공여국의 지출 항 목 가운데 경제 개발 계획, 공공분야 금융 관리, 사법 체계 발전, 시민사회 강화, 선거, 인권, 정보 의 자유로운 흐름, 성 평등 기관 지원 등을 거버넌스 분야의 주요 항목으로 꼽았다 (OECD 2010b).

$\mathrm{IMF}$ 는 거버넌스의 경제적인 면에 주목하고 굿 거버넌스 구축을 위해 수원국의 공공 자원 관리, 투명하고 안정적인 경제 및 규제환경 마련, 민간분야 활동을 위한 지원 등을 강조한다 (Grindle 2007). IMF는 World Bank와 마찬가지로 수원국의 굿 거버넌스에 대한 의지와 개선 상황을 원조 제공 결정의 주요 조건으로 제시하고 있다. 아래〈표 1〉에서 UN, World Bank, OECD, IMF의 굿 거버넌스 목표, 정의, 평가 지표, 거버넌스의 활용을 정리해보았다 (〈표 1〉 참조).

〈표 1〉에서 보듯이 국제기구들 간에 거버넌스에 대하여 상이한 정의를 사용하고 있으며 이에 대한 우려의 목소리도 있다. 영국의 대표적인 개발협력 연구기관인 Overseas Development Institute (ODI)는 거버넌스가 지나치게 많은 것을 포함하려는 'catch-all' 개념이라는 것에 대해 비판적인 논평을 하였다. World Bank나 IMF가 원조를 통해 수원국의 정치에 개입을 한다는 비판을 피하기 위해 거버넌스에 대한 나름대로의 개념을 사용하는 것처럼 공여국과 국제기구들은 거버넌스를 각 자의 입맛에 맞게 해석하고 있다는 비판이 제기되었다 (ODI 2006).

또한, 2002 년 이후 굿 거버넌스의 개념이 지나치게 선진국의 관점에 맞춘 것으로서 개발도상국가 에게는 실현 불가능한 이상향일 뿐만 아니라 개발도상국가에 과도한 규제로 작용한다는 비판적 시 각이 제기되었다. 따라서 수원국의 상황을 고려하고 수원국 관점에서 거버넌스 향상을 위한 접근이 필요하다는 논의가 등장하였다. 이러한 비판적 시각에 맞추어 2002년 이후 개발도상국들에게 보다 실현가능한 'Good enough governance'라는 개념이 새롭게 등장하였다. 'Good enough governance' 는 수원국의 상황을 고려하여 현 단계에서 수원국의 정치·경제 개발을 위해 우선적으로 필요한 요건들을 선택하고 이를 집중적으로 발전시키는 것으로 수원국의 거버넌스 개혁에 대한 부담을 덜 어주며 수원국의 자율성을 높이는 효과를 가져 온다 (Grindle 2007). 
〈표 1〉 주요 국제기구의 굿 거버넌스

\begin{tabular}{|c|c|c|c|c|}
\hline & IMF & OECD & UN & World Bank \\
\hline $\begin{array}{l}\text { 목 } \\
\text { 표 }\end{array}$ & $\begin{array}{l}\text { - 경제적 거버넌스 } \\
\text { - 경제 및 규제환경 개선 } \\
\text { - 민간분야 활성화 }\end{array}$ & $\begin{array}{l}\text { - 원조효과성 향상을 } \\
\text { 위한 거버넌스 } \\
\text { - 수원국의 민주적 } \\
\text { 거버넌스 }\end{array}$ & $\begin{array}{l}\text { • 경제적, 정치적 } \\
\text { 거버넌스 } \\
\text { - 민주주의 달성 }\end{array}$ & $\begin{array}{l}\text { - 경제적 거버넌스 } \\
\text { - 경제발전을 위한 } \\
\text { 시스템 마련 }\end{array}$ \\
\hline $\begin{array}{l}\text { 정 } \\
\text { 의 }\end{array}$ & $\begin{array}{l}\text { - 법치주의 } \\
\text { - 공공분야의 효율성과 } \\
\text { 책임성 } \\
\text { - 부정부패 통제 및 } \\
\text { 척결 }\end{array}$ & $\begin{array}{l}\text { • 국민의 참여 } \\
\text { - 투명성 } \\
\text { • 책임성 } \\
\text { • 법치주의 } \\
\text { • 효과성 } \\
\text { - 평등성 }\end{array}$ & $\begin{array}{l}\text { - 국민의 참여 } \\
\text { - 합의 지향 } \\
\text { - 책임성 } \\
\text { - 투명성 } \\
\text { - 대응성 } \\
\text { - 공정성과 포용성 } \\
\text { - 효과성과 효율성 } \\
\text { - 법치주의 }\end{array}$ & $\begin{array}{l}\text { - 책임성 } \\
\text { - 효율적인 행정 시스템 } \\
\text { - 사법 시스템 }\end{array}$ \\
\hline $\begin{array}{l}\text { 지 } \\
\text { 표 }\end{array}$ & $\begin{array}{l}- \text { Worldwide } \\
\text { Govemance } \\
\text { Indicators(WGI) }\end{array}$ & $\begin{array}{l}\text { - Regulatory Quality } \\
\text { Indicator } \\
\text { - Central Govemment } \\
\text { Debt } \\
\text { - Citizen Relationship } \\
\text { - General Govemment } \\
\text { Account } \\
\text { - Ethics Measures in } \\
\text { Public Service } \\
\text { - Human Resource } \\
\text { Management Survey }\end{array}$ & $\begin{array}{l}\text { - Country Assessment } \\
\text { in Accountability } \\
\text { and Transparency } \\
\text { (CONTACT) } \\
\text { - Democratic } \\
\text { Govemance } \\
\text { Assessments } \\
\text { - Urban Govemance } \\
\text { Index }\end{array}$ & $\begin{array}{l}\text { - Worldwide } \\
\text { Govemance } \\
\text { Indicators(WGI) } \\
\text { - Country Policy and } \\
\text { Institutional } \\
\text { Assessments(CPIA) } \\
\text { - Public Expenditure } \\
\text { and Financial } \\
\text { Accountability }\end{array}$ \\
\hline $\begin{array}{l}\text { 활 } \\
\text { 용 }\end{array}$ & $\begin{array}{l}\text { - Conditionality: } \\
\text { 수원국의 거버넌스 } \\
\text { 개혁과 제도 개선을 } \\
\text { 원조 제공 시 } \\
\text { 조건으로 함 }\end{array}$ & $\begin{array}{l}\text { - 원조평가 } \\
\text { - 공여국의 전략 지원 } \\
\text { - 수원국의 국가별 } \\
\text { 상황분석 }\end{array}$ & $\begin{array}{l}\text { - 개발도상국의 민주화 } \\
\text { 분석 } \\
\text { - 인간개발 }\end{array}$ & $\begin{array}{l}\text { Selectivity : 수원국 } \\
\text { 선정에 굿 거버넌스 } \\
\text { 달성을 위한 수원국 } \\
\text { 의지와 거버넌스 평가 } \\
\text { 결과를 활용 }\end{array}$ \\
\hline
\end{tabular}

출처 : Grindle 2007; OECD 2007; UN 2007; World Bank 2009a.

\section{2. 개발과 거버넌스의 연계성}

OECD/DAC의 '빈곤감소 지침(The DAC Guidelines: Poverty Reduction)'에 따르면 빈곤은 정치, 경제, 사회문화, 인간, 안보 등 다양한 차원으로 구성되어 있다. 따라서 $\mathrm{OECD} / \mathrm{DAC}$ 은 빈곤이 정 치, 경제, 사회의 여러 요인들과 서로 밀접하게 연결되어있기 때문에 개발과정에서 이러한 빈곤의 다면성이 고려되어야 함을 강조한다. 특히 개발도상국의 취약한 거버넌스가 빈곤의 근본적인 원인 이자 지속 가능한 개발을 저해하고 빈곤을 지속시키는 주요인으로 인식되면서 굿 거버넌스 구축을 위한 국제사회의 관심이 대두되기 시작하였다 (OECD 2001). OECD/DAC은 1995년 '참여적 개발 과 굿 거버넌스(Participatory development and good governance)'를 통해 굿 거버넌스의 실현 에 중요한 요소는 곧 개발의 주요소라고 지적하였다. 
앞에서 밝힌 대로, $\mathrm{OECD}$ 는 1995년 이래로 거버넌스의 중요성을 강조하고 있다. 1997년 자체 보 고서를 통해 민주화와 굿 거버넌스를 21 세기 개발 목표 달성을 위한 필수 요소로 보고, 참여적, 효율적 거버넌스만이 지속가능한 사회·경제적 개발을 가능하게 한다고 지적하였다. 또한 이러한 개발과 거버넌스의 통합은 시민사회와 민간부문이 정치·경제 시스템의 개혁에 대해 목소리를 낼 수 있을 때 가능하다는 것을 강조 한다 (OECD 1997).

UN 전 사무총장 코피 아난 역시 1998년 굿 거버넌스를 빈곤 근절과 개발을 위한 유일한 수단으 로 지목하였으며, $\mathrm{ODI}$ 는 국가 간 분석을 통해 거버넌스가 사회·경제적 개발에 긍정적 영향을 미 친다고 주장하였다. ODI 연구에 따르면 굿 거버넌스는 투자와 경제성장으로 이어지는 반면, 부정 부패는 개발에 부정적인 영향을 미치는 것으로 나타났다 (ODI 2006).

\section{III. 거버넌스 네트워크(GOVNET)의 개요}

\section{1. 역사}

거버넌스 네트워크(DAC Network on Governance, GOVNET)는 인권, 부패방지, 거버넌스에 관 련된 업무를 전담하는 $\mathrm{OECD} / \mathrm{DAC}$ 산하기구 중 하나로서, 빈곤퇴치와 지속가능한 개발을 위해 굿 거버넌스가 필수불가결한 요소라는 공감대를 바탕으로 2001년 4월에 설립되었다1).

GOVNET은 개발도상국의 민주적 거버넌스 구축을 위한 공여국 지원의 효과성 제고를 목표로 인 권, 투명성, 책임성, 참여와 평등, 반부패 및 민주적 거버넌스를 위한 역량강화와 함께 개발도상 국이 국가형성시 겪는 어려움 또는 문제점을 분석하고 이에 대한 권고사항을 $\mathrm{OECD} / \mathrm{DAC}$ 회원국 과 산하기구에 제공한다. 또한 회원국 간 경험과 지식을 공유하고 정책 및 분석 도구개발을 논의 할 수 있는 토론의 장을 마련하는 등 거버넌스를 통해서 원조 효과성을 높이는 방안을 마련하기 위해 노력하고 있다 (OECD 2007).

1) 2010년 현재 OECD/DAC은 2개의 실무 작업반과 6 개의 네트워크가 있으며 이는 통계작업반(Working Party on Statistics), 원조효과성작업반(Working Party on Aid Effectiveness), 개발평가 네트워크(Network on Development Evaluation), 성 평등 네트워크(Network on Gender Equality), 환경 및 개발협력 네트워크(Network on Environment and Development Co-operation), 빈곤퇴치 네트워크(Network on Poverty Reduction), 거버넌스 네트워크(network on Governance), 분쟁 및 취약 국제 네트워크 (International Network on Conflict and Fragility) 등이 포함된다. 


\section{2. 구성 및 주요 활동}

\section{1) 구성}

GOVNET2)은 OECD/DAC 회원국들의 개발협력 부처 대표와 개발도상국, 국제기구, 학계 및 NGOs 의 개발협력 전문가들로 구성된 옵서버로 구성되어 있다. 새로운 $\mathrm{OECD} / \mathrm{DAC}$ 회원국인 한국은 아 직 GOVNET의 회원국이 아니다. 의장단과 사무국이 GOVNET의 전체업무를 총괄하며, 9개월마다 파리에서 열리는 총회를 주최한다. 총회에서는 거버넌스와 관련된 다양한 논의가 이루어 질 뿐만 아니라 거버넌스 프로그램을 기획하기도 한다. 사무국은 $2 \sim 4$ 개 회원국으로 구성되며 회의에서 논 의되는 프로그램을 실행하고 총회 외에 상시적으로 열리는 회의를 통해 공여국 및 공여기관 간에 활발한 교류가 이루어질 수 있도록 장려한다. 또한 GOVNET은 $\mathrm{OECD} / \mathrm{DAC}$ 내의 다른 산하기관들 과 협력하여 $\mathrm{OECD}$ 가 거버넌스 이슈와 관련하여 일관성 있는 정책을 수립하고 이행하도록 지원하 고 있다 (OECD 2010a). 다음은 GOVNET의 2010년 조직도이다.

〈그림 1〉 GOVNET 조직도 출처 : OECD 2010a

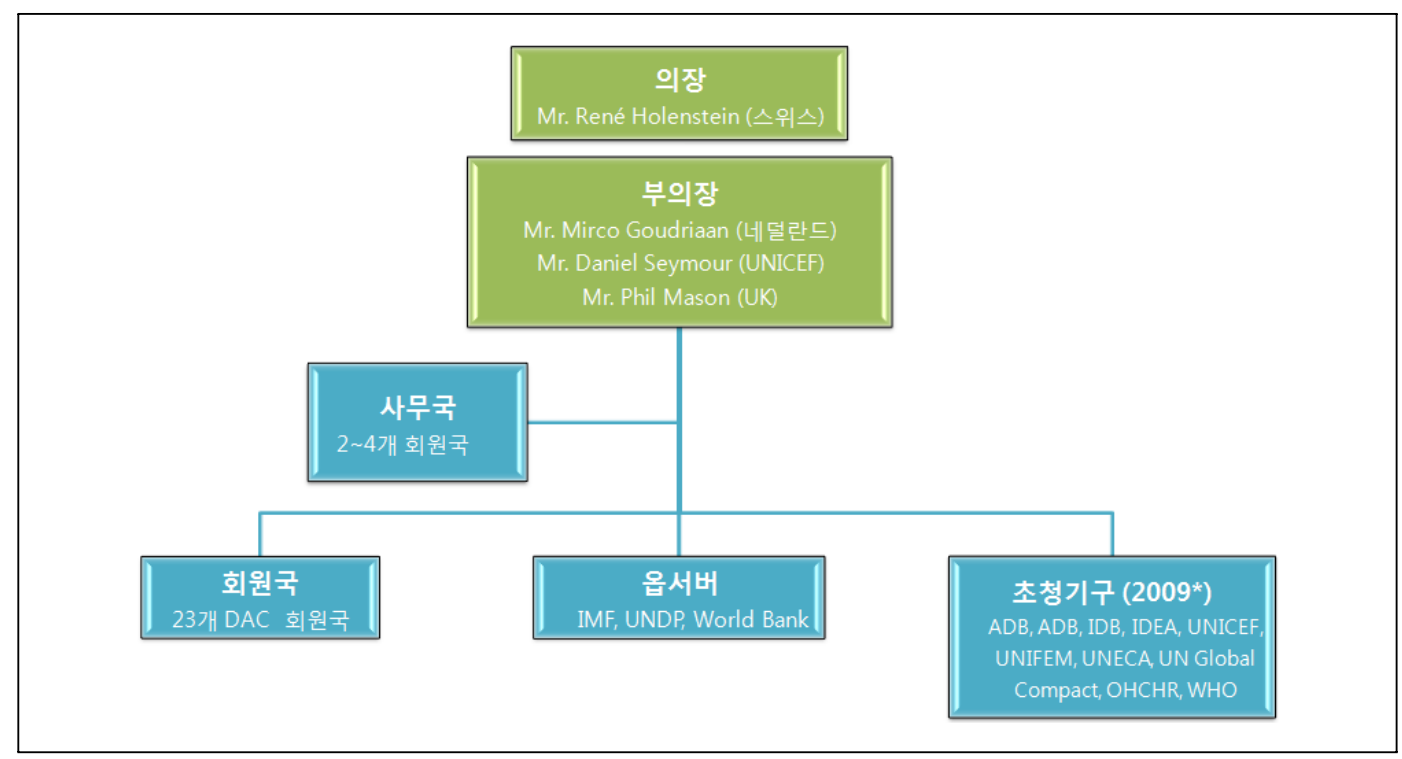

* 초청기구는 옵서버의 자격을 얻어 GOVNET 회원이 된다.

2) GOVNET 회원국은 한국을 제외한 기존의 23 개 OECD/DAC 회원국인 호주, 오스트리아, 벨기에, 캐나다, 덴마크, 핀란 드, 프랑스, 독일, 그리스, 아일랜드, 이탈리아, 일본, 룩셈부르크, 네덜란드, 뉴질랜드, 노르웨이, 포르투갈, 스페인, 스 웨덴, 스위스, 영국, 미국, 그리고 EC (European Commission)와 영구 옵서버인 IMF, UNDP, World Bank, 초청기구 들로 이루어져 있다. 


\section{2) 주요 활동}

GOVNET 회원국 및 주요 공여기관은 좀 더 효율적으로 민주적인 거버넌스를 지원하기 위해 원조 와 상호 책임성, 인권, 부패방지, 거버넌스 평가, 그리고 조세 등의 사안을 우선순위로 정하고, 이 와 관련한 업무를 효과적으로 추진하기 위해 각 사안을 담당할 태스크 팀을 조성하였다. 2010년 현 재, 6개의 태스크 팀이 있으며 여기에는 원조와 국내 책임에 관한 운영위원회, 반부패 태스크 팀, 조세 및 책임 태스크 팀, 인권 태스크 팀, 인권과 분쟁에 관한 공동 작업반, 그리고 거버넌스 평가 운영위원회가 포함되어 있다. 태스크 팀의 주요 활동사안은 아래〈표 2〉와 같다 (OECD 2010a).

〈표 2〉 GOVNET 주요 업무 및 태스크 팀

\begin{tabular}{|l|l|}
\hline \multicolumn{1}{|c|}{ 주요업무 } & \multicolumn{1}{c|}{ 2009 2010 태스크 팀 } \\
\hline $\begin{array}{l}\text { 원조와 국내 책임성 } \\
\text { (Aid and Domestic Accountability) }\end{array}$ & $\begin{array}{l}\text { 원조와 국내 책임에 관한 운영위원회(Steering Group on Aid and } \\
\text { Domestic Accountability) }\end{array}$ \\
\hline $\begin{array}{l}\text { 인권 } \\
\text { (Human Rights) }\end{array}$ & $\begin{array}{l}\text { 인권 태스크 팀(Task Team on Human Rights) } \\
\text { 인권과 분쟁에 관한 공동 작업반(Joint GOVNET/INCAF } \\
\text { (International Network for Children and Families) Working } \\
\text { group on Human Rights and Conflict) }\end{array}$ \\
\hline $\begin{array}{l}\text { 반부패 } \\
\text { (Anti-Corruption) }\end{array}$ & 반부패 태스크 팀(Task Team on Anti-Corruption) \\
\hline $\begin{array}{l}\text { 거버넌스 평가 } \\
\text { (Governance Assessments) }\end{array}$ & $\begin{array}{l}\text { 거버넌스 평가 운영위원회(Steering Group on Governance } \\
\text { Assessments) }\end{array}$ \\
\hline $\begin{array}{l}\text { 조세 } \\
\text { (Taxation) }\end{array}$ & 조세 및 책임 태스크 팀(Task Team on Taxation and \\
Accountability)
\end{tabular}

출처 : OECD 2010a.

원조와 국내 책임성(Aid and Domestic Accountability): 수원국의 취약한 거버넌스가 원조 효과 성 및 수원국 발전을 저해시킨다는 논의가 확산됨에 따라 굿 거버넌스의 중요성이 강조되었으며 책임 있는 정부 구축은 굿 거버넌스의 주요 요인으로 인식되기 시작했다. 책임 있는 정부란 시민 이 정부를 감시하고, 정부가 국민에게 책임을 지는 정부를 말한다. 따라서 GOVNET은 원조와 국 내 책임에 관한 운영위원회를 통해 수원국과 수원국 시민 간의 신뢰를 증진시키기 위한 방법을 모 색하고 수원국에 컨설팅을 제공하며 수원국의 책임성을 강화할 수 있는 시스템 구축에도 노력을 기울이고 있다.

인권 (Human Rights): GOVNET 인권 태스크 팀은 양자 및 다자 원조 기관 사이의 국제 인권 네 트워크로서, 인권과 개발을 통합하여야 하는 당위성 제공 및 공여국의 이해와 합의를 증진시키고 일관성 있는 전략 마련을 위해 노력하고 있다. 인권 태스크 팀은 2009 2010 업무 프로그램을 통 해 인권전문가와 여러 개발정책 커뮤니티 그리고 원조 관리자들 간의 네트워크 형성 및 교류 증진 에 중점을 두고 있다. 인권과 분쟁에 관한 공동 작업반 역시 인권 태스크 팀과 함께 인권 향상을 
위해 활동하고 있다.

부패방지(Anti-Corruption): GOVNET의 반부패 태스크 팀은 공여국과 수원국의 정책입안자들의 공동 대응을 통해 공여국이 수원국의 부패 문제에 효과적으로 대응할 수 있도록 한다. 또한 개발 도상국이 '반부패협약(UNCAC, UN Convention Against Corruption)'을 실행할 수 있도록 지원 하는 동시에 수원국의 부패에 대한 적절한 대응방법에 대한 연구를 통하여 공여국이 효과적으로 부패 문제에 대응할 수 있도록 하는 기본지침을 수립하기 위해 노력하고 있다.

거버넌스 평가(Government Assessments): 거버넌스와 개발의 연계성에 대한 논의가 활발히 진행 되면서 거버넌스 평가의 중요성 또한 주요 이슈가 되었다. 따라서 거버넌스 평가 운영위원회는 2008년 공여국에 대한 연구를 바탕으로 평가도구의 개발과 활용에 대한 연구개발에 착수하였다. 이를 통해 중복평가의 위험을 줄여 거래비용을 감소시켰으며 무엇보다 공여국들의 경험 및 지식 공유, 공여국 정책의 일관성 향상을 유도할 수 있게 되었다.

조세와 책임(Taxation and Accountability): GOVNET은 2007년 조세와 책임 태스크 팀을 조직 하여 공여국과 전문가 간 의견교환을 돕고 있으며, 전문기술 분야에도 거버넌스 관점을 통합하는 동시에 국내자원조달과 조세 분야에 대한 공여국 관련 지침을 제공하고 있다.

이 외에도 GOVNET은 민주적 거버넌스의 투명성 제고에 초점을 두고 국가, 시민사회 그리고 민 간부문 사이의 신뢰 향상 및 협력 문제 또한 다루고 있다.

그러나 GOVNET은 그 주요 회원국과 업무가 공여국에 대한 것이기 때문에 부패 방지 문제 등을 볼 때 공여국의 입장에서 수원국의 문제를 바라본다는 한계가 있다. 이렇기 때문에 수원국의 입장 에서 볼 때, 저개발의 결과로 인해 공식적인 법과 제도가 미비하여 초래된 부패의 문제에 둔감하 고 서구의 일률적인 잣대로 평가한다는 비판도 일부 있다. 간혹 공여국의 정책과 제도가 원치 않 게 수원국의 부패를 조장하기도 한다는 비판도 있다. 또한 GOVNET이 부패에 어떻게 잘 대응할 것인가에 치중하다 보니 부패 척결에는 소홀할 수도 있다. 따라서 GOVNET의 향후 과제는 저개 발의 결과로 불가피하게 발생하는 부패에 대하여 근원적인 척결 방법에 대한 연구, 국제적으로 가 장 청렴한 부정부패 척결을 위한 단계적인 접근방법도 적극적으로 개발해야 할 것이다. 가장 중요 한 것은 이런 모든 연구가 수원국의 사회·경제·정치적 상황에 대한 심층적인 연구 분석에 기초를 두어야 하며, 이 때 수원국 정부, 학계, 민간과 적극적으로 협력하여서 수원국의 주인의식과 책임 성을 그 기본으로 삼아야 실효성 있는 연구와 정책·제도의 개발로 이어질 것이다. 


\section{GOVNET의 정책 논의}

\section{1. 분석틀 및 핵심 과제}

GOVNET은 공여국 중심의 활동을 전개하고 있는 반면, OECD/DAC은 수원국과의 파트너십을 강 조하며 수원국의 굿 거버넌스 구축을 위한 권고사항을 공여국과 수원국 모두에게 제공하고 있다. 다음은 굿 거버넌스 분야에 있어서 $\mathrm{OECD} / \mathrm{DAC}$ 이 권고하는 가이드라인3)을 종합적으로 검토·분석 하여, 그 결과를 토대로 도출한 분석틀로서 이는 새로운 $\mathrm{OECD} / \mathrm{DAC}$ 회원국으로서 우리나라가 준 수해야 할 권고사항 및 원조의 선진화에 필요한 주요 지침이 될 것이다 (김은미 외 2009). 이 분 석틀은 $\mathrm{KOICA}$ 연구과제 '선진원조기관의 $\mathrm{DAC}$ 권고사항 및 평가지표 적용현황과 $\mathrm{KOICA}$ 의 대응 방향 (2010)'의 연구 분석 결과를 기반으로 하였다 (김은미 외 2009).

첫째, $\mathrm{OECD} / \mathrm{DAC}$ 은 수원국이 개발 과정에 적극적으로 참여하는 참여적 개발을 강조한다. 참여적 개발은 1995년 $\mathrm{OECD} / \mathrm{DAC}$ 의 '참여적 개발과 굿 거버넌스(Participatory Development and Good Governance)'에서 수원국의 시민사회와 경제를 강화시키고, 개발협력 프로그램의 효율성과 효과 성 향상 및 지속적인 발전을 꾀할 수 있다는 점에서 그 중요성이 강조된 바 있다. 또한 참여적 개 발에 있어서 '권한 강화'는 민주적 접근을 바탕으로 한 시민사회의 역할 강화를 강조한다. GOVNET 의 전신인 참여적 개발과 굿 거버넌스에 관한 특별조사 위원회의 1997년 최종보고서(Final Report of Ad Hoc Working Group on Participatory Development and Good Governance)에 따르면 수원국의 민주화는 시민사회의 다양성을 강화하고 여성의 정치·경제 참여를 지원하며 정보의 접 근성을 향상시켜 수원국의 진정한 참여적 개발을 꾀하며, 궁극적으로 수원국의 굿 거버넌스 구축 과 원조의 효과성 향상에 영향을 미친다.

이러한 민주화의 달성을 위해서는 수원국 정부의 정당성과 의지, 리더십이 필수적이며, 동시에 공 여국은 모든 사회분야의 정책개발 및 정책대화에 참여함으로써 민주화를 지원해야 한다. 따라서

3) OECD (1997), "Final Report of the Ad Hoc Working Group on Participatory Development and Good Governance, Part I \& II," Paris: OECD; OECD (1995), "Participatory Development and Good Governance," Paris: OECD; OECD (1997), "The Design and Use of Capacity Development Indicators," Paris: OECD; OECD (2008), "Governance, Taxation and Accountability: Issues and Practice," Paris: OECD; OECD (2006), "Principles for Donor Action in Anti-Corruption," Paris: OECD; OECD (2003), "Map-Making and Analysis of the Main International Initiatives on Developing Indicators on Democracy and Good Governance," Paris: OECD; OECD (2006), "The Development Dimension: Integrating Human Rights into Development: Donor Approaches, Experiences and Challenges," Paris: OECD; OECD (2006), "The Challenge of Capacity Development: Working Towards Good Practice," Paris: OECD; OECD (2007), "Policy Paper and Principles on Anti-Corruption: Setting an Agenda for Collective Action," Paris: OECD. 
공여국은 수원국 내 정당 간 협력 및 시민사회의 의사결정 과정에의 참여를 지원하고, 수원국이 주인의식을 바탕으로 사회적 합의를 도출할 수 있도록 민주적 다원성의 토대 확립을 지원해야 한 다. 또한 민주적 분권화를 통해 수원국의 효과적인 업무 분담 및 시민의 지역사회 참여를 장려하 여 국가 역량 및 거버넌스 강화에 기여해야 한다. 이와 더불어 수원국의 시민사회는 민주화에 대 한 필요와 지지를 표명하고, 정치적 과정에서 소외되는 집단을 대표하여 관련 국가 정책 등에 대해 발언하고 대중의 참여를 이끌어 내며, 사회 내 다양한 그룹들을 연결하는 역할을 수행해야 한다.

둘째, $\mathrm{OECD} / \mathrm{DAC}$ 은 수원국의 인권 보호와 인권 신장에 기여하는 개발협력을 강조한다. 1993년 비엔나 세계인권회의에서 인권 보호가 빈곤감소와 경제개발 및 안보에 긍정적 영향을 끼침을 확인 한 이래, 개발협력과 원조 집행에 있어서 인권의 중요성이 강조되었다. 최근에는 대다수의 공여국 및 공여기관이 인권에 관한 정책을 명시하고, 수원국의 인권신장을 위해 재정적·기술적 지원을 하 고 있다. GOVNET의 연구에 근거하여 발표된 2006년 $\mathrm{OECD/DAC}$ 의 '개발에서의 인권: 공여국의 관점, 경험과 과제(The Development Dimension: Integrating Human Rights into Development: Donor Approaches, Experiences and Challenges)'에 따르면 인권 보호를 위한 구체적 방안으로 $\mathrm{OECD} / \mathrm{DAC}$ 은 인권에 기반을 둔 접근법(Human Rights-based Approaches)4), 인권 주류화(Human Rights Mainstreaming)5), 그리고 인권정책대화(Human Rights Dialogue)6)를 제시하고 있다. 특 히 수원국의 거버넌스 개발 지원 시 수원국의 인권 보호와 신장에 대한 목표를 개발에 보다 명확 하게 통합할 것을 권고하고 있다.

셋째, $\mathrm{OECD} / \mathrm{DAC}$ 은 투명성 및 책임성 제고를 강조한다. 이를 위해 수원국의 과도한 군사비용을 절감할 것을 권고하고 있다. 이를 위해서는 수원국 내 효과적이고 효율적인 안보전략을 개발하고, 군사예산에 대한 투명성과 조정능력을 확보해야 한다. 또한 행정 절차의 투명성 및 책임성 강화는 물론 행정사무와 회계에 관한 교육을 통해 수원국의 공공 분야 관리 역량을 강화할 것을 권고하고 있다 (OECD 1995, 1997). 이와 관련하여 조세제도 정비 및 부정부패 방지를 통한 거버넌스의 강 화를 강조한다.

또한 GOVNET은 2007년 '조세 및 책임성에 대한 태스크 팀(Tax and Accountability Task Team)' 을 조직하고 조세 지원과 거버넌스의 관계에 대한 연구를 착수하여 2008년 '거버넌스, 조세 및 책 임성(Governance, Taxation and Accountability: Issues and Practices)'을 발간하였다. 이 연구

4) 인권 보호를 주요 목표로 삼아 개발 분야 전반에 걸쳐 변화를 주도해야 한다는 접근법.

5) 현행 원조 분야에 인권을 통합하기 위한 노력을 기울여야 한다는 접근법.

6) 수원국과 공여국 간 논의를 통해 인권 보호를 위한 협력을 증진하고, 인권 침해가 발생하는 경우 원조의 방식과 규모 의 변화에 대한 논의가 이루어질 수 있다는 접근법. 


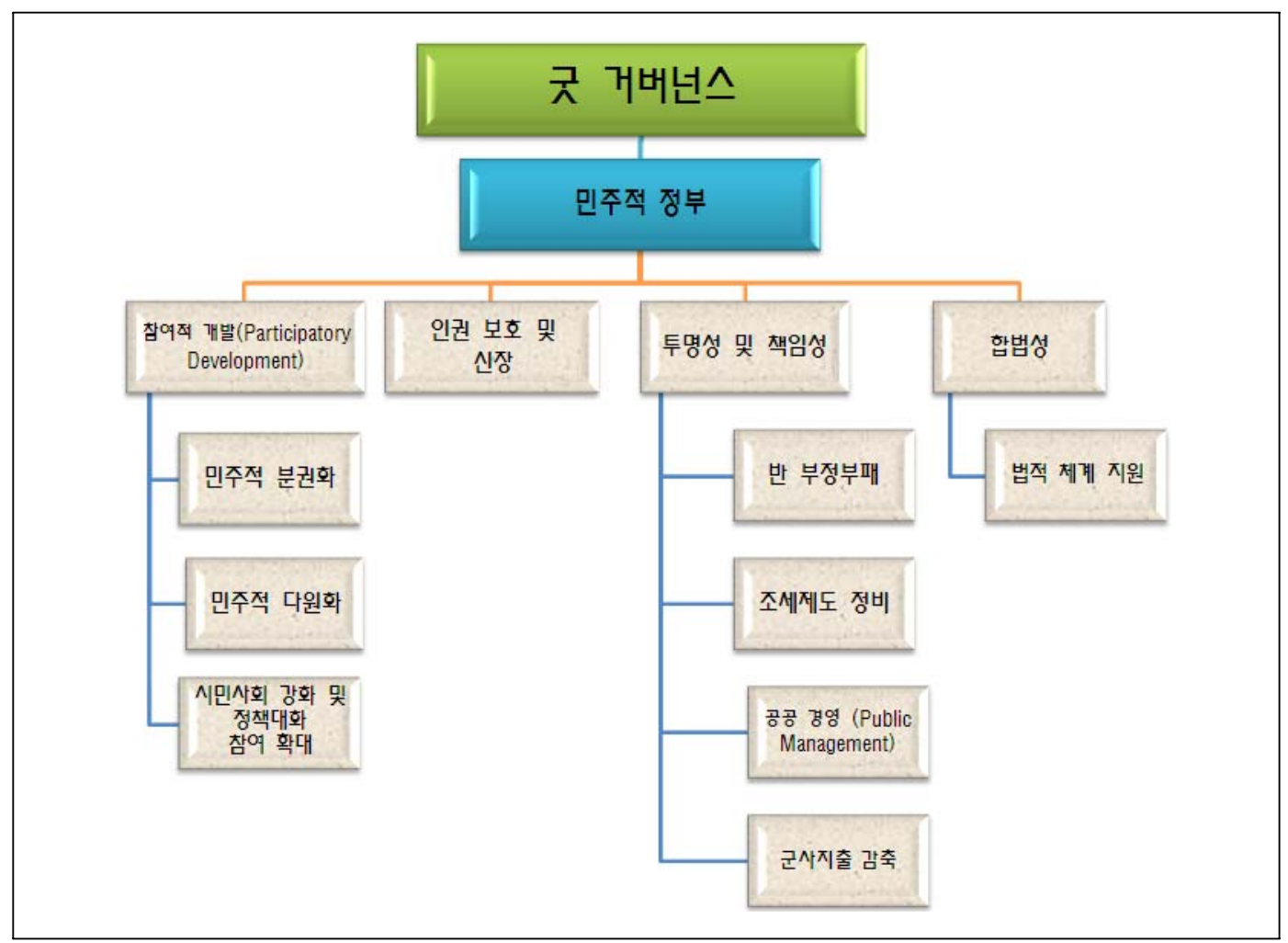

출처 : 김은미 외 2009.

결과에 따르면 조세 제도 개선은 공여국과의 책임 관계 형성 및 수원국 역량 강화에 기여하여 수 원국의 굿 거버넌스 구축에 영향을 미치는 것으로 나타났다. 따라서 수원국은 세제개혁의 핵심 요 소7)를 바탕으로 정부, 민간분야, 시민사회의 재정협정 등을 통해 조세 제도 개선에도 힘써야 한 다. 공여국은 수원국의 역량강화 지원 및 세제개혁을 위해 국제 조세 전문가와의 대화채널을 구축 하는 등 수원국의 세입 증대를 지원해야 한다.

부정부패 척결을 위해 OECD/DAC은 2006년 '부패방지를 위한 공여국의 활동 원칙(Principles for Donor Action in Anti-Corruption)'을 마련하였다. OECD/DAC은 부패방지를 위해 공여국간 협력 강화를 강조하고 수원국의 부패방지 대책 마련에 수원국 내 시민단체, 미디어, 민간기업 등 주요 단체의 참여를 독려하며, 이를 위해 이들 단체의 역량개발 지원과 모니터링 기능을 강화할 것을 권고하였다.

7) 세제개혁의 핵심 요소는 첫째, 무역세의 의존도 감소 및 소비세(부가가치세, VAT) 부가, 둘째, 세제의 간소화, 셋째, 세 무 행정제도의 강화이다(OECD 2008, p. 22). 
넷째, $\mathrm{OECD} / \mathrm{DAC}$ 은 수원국의 법적 환경 조성과 법률 시스템 강화를 통해 수원국에 법치주의를 확 립할 것을 권고한다. 1995 년 $\mathrm{OECD} / \mathrm{DAC}$ 의 '참여적 개발과 굿 거버넌스(Participatory Development and Good Governance)'와 1997년 '참여적 개발과 굿 거버넌스에 관한 실무 작업반의 최종 보고 서(Final Report of the Ad Hoc Working Group on Participatory Development and Good Governance)'에 따르면 효율적이고 합법적인 법적 체계의 확립은 수원국의 굿 거버넌스 뿐만 아 니라 민주화와 인권 보호 달성을 위해 필수적인 요소이다. 따라서 공여국은 수원국 내 독립적인 사법체계 구축을 지원하고 여성 및 소외계층의 인권보호를 보장하는 법률 마련을 위해 기술적 지 원을 제공해야 한다. 또한 $\mathrm{OECD} / \mathrm{DAC}$ 은 법률 시스템 개발 등을 통해 수원국의 전반적인 법적 환 경 개선을 위해 공여국이 노력할 것을 제안하고 있다.

\section{2. 공여국 전략}

위의 분석틀과 핵심과제는 $\mathrm{OECD} / \mathrm{DAC}$ 이 공여국과 수원국에 제공하는 주요 가이드라인을 바탕으 로 분석한 것이다. 다음은 가이드라인의 권고사항 중 $\mathrm{OECD} / \mathrm{DAC}$ 이 공여국에 제안하는 전략내용 을 분석한 내용이다.

$\mathrm{OECD} / \mathrm{DAC}$ 은 먼저 수원국의 굿 거버넌스 달성을 위해 공여국에게 장기적이고 전략적인 프레임워 크 안에서 개발협력을 추구할 것을 권고하고 있다. 이를 위해 $\mathrm{OECD} / \mathrm{DAC}$ 은 공여국이 굿 거버넌 스 달성을 위한 수원국과의 장기적인 파트너십을 구축하고 이를 통해 수원국 정부의 투명성과 신 뢰성을 향상시킬 것을 권고한다.

또한 $\mathrm{OECD} / \mathrm{DAC}$ 은 수원국의 주인의식 강화를 위한 지원을 강조한다. 공여국은 수원국의 주인의 식 함양이 개발협력의 중점적인 목표가 되어야 함을 인식하고, 정책분석 등을 통해 수원국의 참여 적 개발과 거버넌스 개선을 위한 수원국의 역량 강화를 지원해야 한다.

이와 더불어 공여국은 수원국 내 시민사회의 역할과 책임에 대한 인식제고를 통해 수원국 시민사 회의 전략적 역할을 확대시켜야 한다. 특히 분쟁 발생 이후라면, 공여국은 갈등세력간의 합의 도출 과정에 시민사회가 적극 참여할 것을 권고하며 이를 위해 시민사회의 역량강화 지원을 강조한다.

마지막으로 $\mathrm{OECD} / \mathrm{DAC}$ 은 공여국의 인권에 기반을 둔 접근법을 강조하고 공여국의 원조 목표 및 활동에 인권문제를 통합할 것을 권고한다. 인권 중심의 개발원조는 갈등을 유발할 수 있는 종교적· 문화적·정치적 요인들을 국가별 상황에 맞게 분석하고 이해하는 것이 핵심이므로, 공여국은 수원국 
상황에 대한 정확한 이해를 바탕으로 수원국과 파트너십을 강화하고 수원국 내에서 인권 관련 정책 을 효과적으로 집행할 수 있도록 지지기반을 구축해야 한다. 이와 함께 공여국은 인권 신장을 위 한 국제적 합의에 부합하는 개발협력 정책을 개발하고 수원국의 인권 정책 수립을 지원해야 한다.

〈그림 3〉 굿 거버넌스를 위한 공여국의 전략

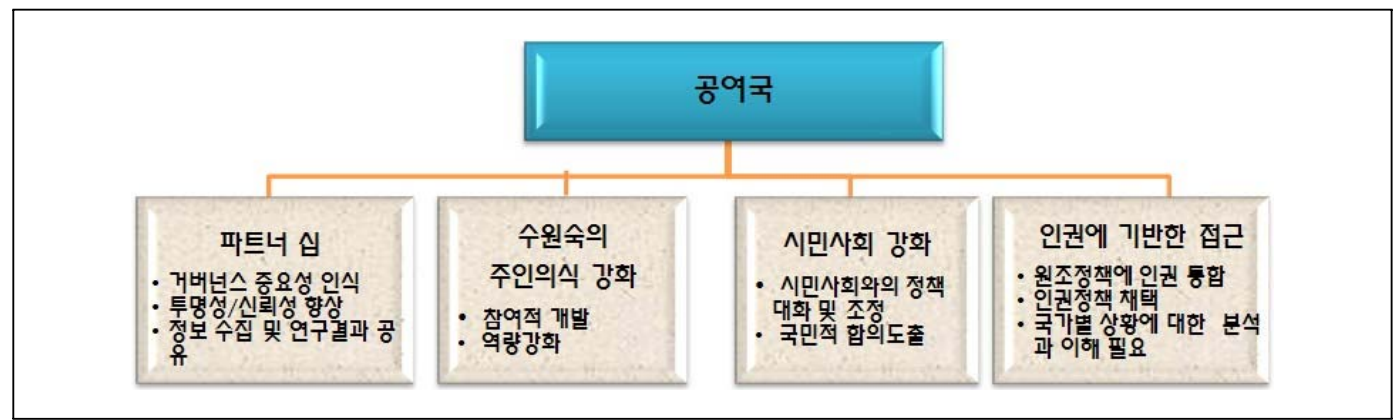

출처 : 김은미 외 2009.

위의 $\mathrm{OECD} / \mathrm{DAC}$ 이 권고하는 공여국 전략과 GOVNET의 활동을 비교해 볼 때, $\mathrm{OECD} / \mathrm{DAC}$ 은 수 원국 관점 및 상황에 대한 이해를 바탕으로 수원국의 민주화를 위한 제도와 환경 조성을 강조한 다. 특히 시민사회 지원을 통해 참여적 개발, 민주적 다원화를 촉진하고 성숙한 민주주의로 발전 할 수 있는 기반을 마련할 것을 권고하고 있다. 책임성, 인권, 부패 방지, 조세제도 정비 등의 활 동은 GOVNET과 $\mathrm{OECD} / \mathrm{DAC}$ 이 공통적으로 추구하는 항목이다.

\section{V. 한국의 거버넌스 지원 ODA 현황}

$\mathrm{OECD}$ 가 제공하는 통계자료 (International Development Statistics)8)에 따르면 한국의 거버넌스 분야 지원은 2006 년 5,610 만불, 2007 년 8,640 만불 2008 년 6,310 만불로 각각 전체 원조의 약 $14 \%, 16 \%, 11 \%$ 를 거버넌스 분야에 지원해 왔다. 거버넌스에 대한 한국의 지원은 대부분 KOICA 를 중심으로 기획재정부와 행정안전부가 함께 집행해 왔다.

\section{1. $\mathrm{KOICA}$ 의 굿 거버넌스 전략 및 지원 활동}

1991년부터 2005년까지 거버넌스에 대한 KOICA의 원조 규모는 전체 무상원조의 $19.8 \%$, 유상원

8) OECD가 제공하는 International Development Statistics는 2006년 이후의 한국 원조에 관한 통계를 제공하고 있다. 
조의 $3.1 \%$ 를 차지한다 (KOICA 2007) $)^{9}$. 거버넌스는 $\mathrm{KOICA}$ 의 8개 중점 사업 분야 중 하나로 2008년 KOICA는 전체 ODA 총액의 $14.3 \%$ 에 달하는 3,930 만불을 거버넌스 분야에 지원했다 (KOICA 2009). KOICA는 경제개발 추진능력 강화, 행정능력 및 혁신역량 개발 및 강화, 법 체제 정비 및 사회 안정 지원, 민간 경제 활성화를 거버넌스 주요 목표로 세우고 $\mathrm{ODA}$ 사업을 집행하고 있다(KOICA 2010). 다음은 KOICA가 실행하는 거버넌스 분야의 ODA 프로젝트이다.

1) 경제개발역량 강화: 중장기 경제개발계획 수립, 경제연구소 설립 및 운영지원, 공기업 민영화 전략 수립, 산업개발정책 수립 등의 사업

2) 행정능력 개선: 공무원 능력개발, 공기업 경영 기법 전수, 공공기관 구조 개선, 공정한 평가제 도 구축, 공공행정 전산화, 정부 혁신 등을 통해 행정능력 개선 지원

3) 법률체계 구축: 법률 체계 구축, 범죄예방 및 국제사법 공조체제 구축, 법조인 훈련, 사법제도 개혁, 선거관리행정역량 강화, 지역 균형발전 및 지방행정 강화 등 법률체계 구축 지원 사업

4) 민간경제 활성화: 중소기업 육성정책 수립, 투자유치 전략 수립, 국제 무역인력 양성, 무역 진 흥기구 설립, 수출 진흥 정책 수립, 경제특구 개발 지원

KOICA는 1991년부터 2005년까지 연수생 초청 프로그램(18.5\%)을 통한 경제정책 및 개발전략 등 한국의 개발 경험 전수와 행정 분야 업무 시설 여건 개선을 위한 관련 기자재 제공 등의 물자 지 원 사업(70.7\%)을 중심으로 수원국의 거버넌스 지원 프로그램을 실행해 왔다. 이러한 지원은 특정 행정 제도 분야의 체계적인 역량 발전 프로그램이라기보다는 행정 및 제도 운영을 위한 개인 역량 개발로서, 인적자원 개발을 중점으로 한 프로그램이라고 볼 수 있다(한국개발전략연구소 2007).

경제개발 중심의 $\mathrm{KOICA}$ 거버넌스 지원 프로그램은 $\mathrm{UN}$ 과 $\mathrm{OECD}$ 가 제안하는 정치적·민주적 거버 넌스와는 달리 World Bank의 경제적 거버넌스 개념에 초점을 맞추고 있다. 이는 많은 선진공여 국들이 수원국의 정치적·경제적·행정적 거버넌스 향상을 위해 지원 분야를 확대하는 것과는 다른 접근법이다. 또한 $\mathrm{OECD} / \mathrm{DAC}$ 의 가이드라인에 비추어 볼 때, $\mathrm{KOICA}$ 의 거버넌스 지원 활동은 수 원국의 법적 제도 개선 및 역량 강화에 관한 권고사항에는 부합하나 $\mathrm{OECD} / \mathrm{DAC}$ 이 권고하는 민주 주의, 인권, 시민사회와의 협력과 관련한 활동은 거의 이루어지고 있지 않으며 수원국 거버넌스의 평가도 이루어지고 있지 않다. 따라서, 향후에 $\mathrm{KOICA}$ 를 비롯한 한국의 ODA가 어떤 목적성을 가 지고, 어떤 프로그램을 개발할지에 대한 연구와 범정부적 합의가 필요하리라고 본다. 특히 과거 실행했던 프로그램에 대한 평가가 주요 결정요인이 되어야 할 것이다. 이와 더불어 $\mathrm{KOICA}$ 와 타 무상원조 집행기관들의 역량강화를 위해서 꾸준히 노력하여야 할 것이다. 많은 $\mathrm{EU}$ 국들이 사용하

9) 제시된 통계는 2007년 발표된 KOICA 자료로 2005년까지의 KOICA 거버넌스 분야 원조만 집계된 것이다. 
고 있는 Program (Project) Cycle Management를 적극적으로 도입·적용하는 문제도 고려하여야 할 것이다.

\section{2. 기획재정부의 거버넌스 지원}

기획재정부는 원조 규모에 관한 통계를 제공하고 있지 않기 때문에 거버넌스 지원 비중은 알 수 없 으나 2004년부터 2009년까지 총 15개국에서 경제발전경험 공유 사업(Knowledge Sharing Program, $\mathrm{KSP})$ 을 시행해 오고 있다. KSP는 한국의 경제발전경험을 토대로 한국개발연구원과 같은 전문 개 발기관의 연구 용역을 통해 개발도상국에 정책 컨설팅을 제공하는 사업이다. 이 프로그램은 정책 운영 및 수립을 위한 역량 개발, 주요 이슈에 대한 해결책 모색, 상호우호적인 관계 구축을 목표 로 하고 있다. 2009년에는 베트남에 경제정책 전반에 걸쳐 정책자문을 제공하는 '포괄적 컨설팅' 을 실시하였으며 점차 아프리카·남미·중앙아시아 등으로 협력 지역을 확대해 가고 있다.

기획재정부의 거버넌스 지원 사업은 부처의 특성상 경제적 관점에 국한하여 원조를 집행하고 있 다. 따라서 주요 활동은 경제 개발 관련 역량 개발 및 개발 경험 컨설팅 제공에만 한정되어 있어 서 참여적 개발, 인권 신장, 정부의 투명성·책임성·합법성 제고와 같은 $\mathrm{OECD} / \mathrm{DAC}$ 가이드라인의 주요 권고사항을 충족하지 못한다. 또한 $\mathrm{KOICA}$ 는 물론 거버넌스를 지원하는 다른 부처들과의 협 력을 위한 제도도 마련되어 있지 않다. 따라서 기획재정부가 안고 있는 큰 과제는 2009년 11월에 국회에서 통과된 ‘국제개발협력기본법’에 따라서 $\mathrm{KSP}$ 와 같은 무상원조 사업을 진행할 때 어떻게 외교통상부와 조화로운 조율과 협력을 통해서 효과적인 원조를 할 것이냐에 있다. 그러면 자연스 럽게 무상원조의 전체적인 틀 안에서 여러 부처와 집행기관간의 원조 목표와 프로그램들이 중복되 지 않으면서 최상의 시너지를 구가할 수 있을 것이다.

\section{3. 행정안전부 거버넌스 지원 사업}

행정안전부는 지방행정연수원을 통해 2001년부터 지금까지 약 200여명을 대상으로 거버넌스 지원 을 위한 다양한 프로그램을 실시해왔다 (행정안전부 2010). 기획재정부와 마찬가지로 행정안전부 가 개발도상국에 제공하는 원조에 대한 통계 자료는 제공되지 않고 있다. 행정안전부는 연수사업 을 통해 한국 지방정부의 굿 거버넌스, 재정체계 및 전자정부 구축 등 한국 국가발전 및 지방행정 의 경험을 바탕으로 몽골을 포함한 개발도상국에 거버넌스를 지원하고 있다.

행정안전부의 원조 사업은 최근 강조되는 전자정부 구축을 중심으로 행정적 거버넌스 분야를 집중 
적으로 지원하고 있으나 $\mathrm{UN}$, World Bank, $\mathrm{OECD}$ 가 규정하는 정치적·경제적 거버넌스에 대한 지 원은 이루어지고 있지 않다. 따라서 $\mathrm{KOICA}$ 와 기획재정부와 마찬가지로 거버넌스의 정치적·경제 적·행정적인 면을 포괄하여 지원할 것을 권고하는 $\mathrm{OECD} / \mathrm{DAC}$ 가이드라인의 권고사항은 충족하지 못한다. 또한 수원국의 행정 역량 강화에 초점을 두고 연수사업의 형태로만 진행되고 있어서 거버 넌스 지원을 위한 다양한 전략 및 접근법 개발이 필요하다. 이와 더불어 다른 원조기관 및 관련 정부 부처와의 협력도 이루어지고 있지 않다. 따라서 한국정부의 전체적인 원조 목표 아래 일관성 있게 원조가 이루어질 수 있도록 위에서 지적한 바와 같이 기본법에 따라서 외교통상부와 함께 거 버넌스 사업들을 조율하여 원조규모는 크지 않더라도 효과성은 높은 원조가 이루어지도록 노력해 야 할 것이다.

\section{VI. 한국 거버넌스 지원에 대한 평가 및 정책 제언}

\section{1. 한국 거버넌스 지원에 대한 평가}

한국의 거버넌스에 대한 지원은 기본적으로 한국의 발전 경험 공유를 중심으로 이루어지고 있다. $\mathrm{KOICA}$ 를 비롯하여 행정안전부와 기획재정부의 거버넌스 관련 원조 프로그램은 한국의 개발 경험 공유 및 기술 전수를 바탕으로 연수생 초청 프로그램을 통한 인적자원 개발과 역량강화 지원 및 정책 컨설팅 제공이 대부분이다. 한국의 거버넌스 분야 지원은 $\mathrm{OECD} / \mathrm{DAC}$ 이 권고하는 수원국의 민주화와 인권보호를 위한 프로그램이나 정책은 마련되어 있지 않은 채 연수사업과 기자재 제공에 만 의존하고 있다. 또한 $\mathrm{KOICA}$ 를 비롯하여 기획재정부와 행정안전부가 거버넌스 지원 사업을 벌 이고 있으나 이들 기관들 간의 협력을 위한 도구나 제도 또한 마련되어 있지 않아 기관 간의 정책 및 프로그램의 일관성에 대한 의문도 제기된다. 부처별 전문성을 살려 원조를 제공하는 것은 바람 직하나 협력의 부재와 평가 및 통계 자료의 부족은 개선이 시급하다. 특히 $\mathrm{OECD} / \mathrm{DAC}$ 이 원조의 효과성 제고를 위해 강조하는 원조 평가와 통계자료 구축에 관한 노력이 우선시 되어야 한다.

원조 프로그램 및 전략 개발에 있어서 또 하나의 중요한 과제는 $\mathrm{OECD} / \mathrm{DAC}$ 의 권고사항 및 공여 국 전략의 도입과 반영이다. 특히 참여적 개발, 인권 보호 및 신장, 투명성 및 책임성, 파트너십 구축, 수원국의 주인의식 강화를 위한 지원은 거의 이루어지고 있지 않은데, 이에 대한 논의, 검 토와 그에 따른 정책 변화가 필요하다.

또한 앞서서 권고한 바와 같이 한국 내 각 원조 집행기관들의 역량강화와 범정부적 시스템 구축을 
위하여 Program/Project Cycle Management (PCM)의 도입과 실행도 적극적으로 검토해야 할 것 이다.

\section{2. 거버넌스 $\mathrm{ODA}$ 의 선진화를 위한 정책 제언}

거버넌스 $\mathrm{ODA}$ 의 선진화를 위한 정책 제언은 크게 국제적, 국가적, 국내 기관 차원에서 생각해볼 수 있다 (〈표 3〉 참조).

〈표 3〉 국제적, 국가적, 국내 기관 차원의 정책제언

\begin{tabular}{|c|c|c|c|}
\hline 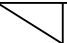 & 국제적 & 국가적 & 국내 기관 \\
\hline $\begin{array}{l}\text { 정 } \\
\text { 책 } \\
\text { 제 } \\
\text { 언 }\end{array}$ & $\begin{array}{l}\text { - OECD/DAC 내의 기관 및 } \\
\text { 공여국들과의 협력 }\end{array}$ & $\begin{array}{l}\text { - 거버넌스에 대한 목표와 개념 } \\
\text { 정립 } \\
\text { - 중점분야 및 예산 분배 결정 } \\
\text { - 거버넌스 지원 분야 및 전략 개발 } \\
\text { - 수원국과의 협력도모 }\end{array}$ & $\begin{array}{l}\text { - 집행기관 간의 협력체계 마련 } \\
\text { - 원조 관리 및 평가 실시 } \\
\text { - } \mathrm{PCM} \text { 의 도입과 활용 } \\
\text { - ODA 전문 기관과 전문가의 } \\
\text { 역량 강화 }\end{array}$ \\
\hline
\end{tabular}

첫째로, 국제무대에서 한국이 중추적인 역할을 하기 위해서는 GOVNET을 포함한 OECD/DAC 내 의 기관 및 여러 공여국들과의 협력 구축 방안에 대한 논의가 이루어져야 한다. 한국은 $\mathrm{OECD/}$ $\mathrm{DAC}$ 회원국으로서 앞으로 GOVNET을 비롯하여 $\mathrm{OECD/DAC}$ 내 여러 네트워크에서 활동하게 될 것이다. 따라서 한국이 리더십을 발휘하면서 중추적인 활동을 하고자 하는 네트워크를 전략적으로 선정해야 할 것이며, 그 가운데 한국이 책임 있게 기여할 수 있는 분야와 역할을 결정해야 한다.

특히 조세제도 및 공공경영 체계 구축을 포함한 한국의 개발 경험은 개발도상국에 보다 실질적인 정 보 제공 및 정책 제언의 기회가 될 수 있을 것이다. 한국은 그동안의 개발 경험을 바탕으로 GOVNET 을 새로운 전략과 실천 모색을 위한 기회의 장으로 활용한다면 한국은 세계 $\mathrm{ODA}$ 의 장에서 중요 한 리더십을 발휘할 수 있을 것이다.

두 번째 국가적 차원에서 한국은 먼저 거버넌스에 대한 목표와 개념을 정리할 필요가 있다. 거버 넌스의 개념은 경제적 거버넌스에서 민주화와 인권을 포함한 포괄적인 것으로 점차 발전되어 왔 다. 그러나 한국은 거버넌스 개념에 대한 심층적 논의 없이 경제적 거버넌스에 초점을 기울여 왔 다. 또한 각 부처들은 부처별 특성 및 전문성에 국한하여 연수와 기자재 제공 중심의 원조프로그 램을 운영해 왔다. 따라서 한국 정부 전체 차원에서 거버넌스의 중요성 (집중 지원 분야 지정 여 부), 규모, 프로그램 및 수원국 선정에 대한 충분한 검토와 합의가 필요하고, 이러한 범정부적인 접근에 의거하여 각 부처가 집행을 위한 적절한 역할 분담을 해야 할 것이다. 
마지막으로 국내 원조 집행기관 차원에서 생각해 볼 때, 한국은 집행기관 간의 협력체계와 인적 역량 강화를 위한 체제 마련이 시급하다. 현재 부처별로 산발적으로 집행되고 있는 원조를 관리하 고 평가할 수 있는 조직 및 제도를 마련하여 원조 집행의 중복을 방지하고 효과적이고 일관성 있 는 원조 집행이 이루어질 수 있도록 해야 한다. 또한 원조 일관성·효과성 제고를 위해 공여기관 간의 협력 메커니즘을 마련하고 평가 도구와 평가 결과의 환류를 위한 방안을 모색해야 할 때이다. 이를 위해서 $\mathrm{EU}$ 의 여러 회원국들을 비롯한 여러 공여국들과 국제기구에서 사용하고 있는 $\mathrm{PCM} 10$ ) 의 도입과 활용을 적극적으로 검토해야 할 것이다.

이와 함께 한국 내 $\mathrm{ODA}$ 거버넌스 관련 전문 기관과 인적자원 개발을 위한 제도적·예산적 지원이 증대되어야 할 것이다. 정부와 주요 집행기관에 필요한 기구의 설립, 인적 자원의 증가 및 이를 위한 예산 책정이 필수적이다. 또한 원조에 대한 다양한 접근법 및 프로그램 개발을 위해 인적 교 류, 경험과 정보 공유, 인적 개발 기회를 시민사회에게도 적극적으로 제공함으로써 공여국으로써 의 전반적인 역량 개발에 힘써야 할 것이다.

한국은 $\mathrm{OECD} / \mathrm{DAC}$ 회원국이 되면서 세계사회에서 원조 공여국으로서의 책임을 다하고자 이를 세 계에 천명하였다. 따라서 한국에 대해 많은 선진 원조 공여국들과 수원국들의 관심이 높아졌으며, 이러한 높아진 관심과 더불어 더 엄중한 잣대로 한국의 원조를 평가하게 될 것이다. 한국은 이러 한 세계의 관심과 집중 조명에 대해 부끄럽지 않고, 무엇보다도 한국 국민들이 자랑스러워 할 수 있도록 적극적으로 선진적이고 수원국 관점에서, 따뜻한 마음으로부터 우러나오는 원조를 집행하 도록 거버넌스 원조 분야를 선진적으로 구축하는 것이 우리의 과제일 것이다.

10) $\mathrm{PCM}$ 은 미국을 중심으로 활용되고 있는 Logical Framework Approach (LFA)와 비교할 때 평가와 그에 따른 환류 (Feedback)를 주요 요소로 추가하여 원조집행을 보다 효과적으로 관리하는 기재로 인정받고 있다. 


\section{참고 문헌}

권율, 김영혜, 박수경, 이태주, 이현주, 정유아, 정지선, 정지원, 정혜선, 조미진, 한재광, ${ }^{\circledR} \mathrm{OECD} / \mathrm{DAC}$ 주요 규범과 $\mathrm{ODA}$ 정책 개선방안』(서울: 대외경제정책연구원, 2009).

기획재정부, 『09년 경제발전경험 공유사업(KSP) 본격 궤도에 오르다』(서울: 기획재정부, 2009).

기획재정부, 『한국의 경제발전경험을 국가 브랜드화하여 개도국에 적극 전파해 나가기로』 (서울: 기획재정부, 2008).

김은미, 김지영, 김지현, 조혜림, 『선진원조기관의 $\mathrm{DAC}$ 권고사항 및 평가지표 적용현황과 $\mathrm{KOICA}$ 의 대응방향』 KOICA 연구보고서. (서울: KOICA, 2010).

박명지, “KOICA 범분야(크로스커팅) 정책 통합 방안,” 『한국국제협력단 개발정책포커스』 제1호 (서울: KOICA, 2010), p.52-68.

전승훈, 이경구, 이재홍, 손성애, 『한국적 개발협력 프로그램 발전방안 연구』(서울: KOICA, 2007).

지방행정연수원, 『한국 지방행정 배우러 몽골에서 왔어요』(수원: 지방행정연수원, 2010).

한국국제협력단, “행정제도/추진방향," http://www.koica.go.kr (검색일: 2010년 8월 26일).

한국국제협력단, 『2009. 연차보고서』(서울: KOICA, 2009).

행정안전부 보도자료. "한국 지방행정 배우러 몽골에서 왔어요! 지방행정연수원, 몽골 지자체 공무원 23명 연수 실시” (서울: 행정안전부, 2010년 7월 26일).

Burnside, Craig and David Dollar, 2000. "Aid, Policies, and Growth.” The American Economic Review, Vol. 90, No. 4 (2000).

DCD/DAC/GOVNET, Synthesis of Lessons Learned of Donor Practices in Fighting Corruption (Paris: OECD, 2003).

Dollar, David and Lant Pritchett, Assessing Aid: What Works, What Doesn't and Why? (Washington, DC: World Bank, 
Easterly, William, Ross Levine and David Rodman, “Aid, Policies, and Growth: Comment.” The American Economic Review, Vol. 94, No. 3 (2004).

Grindle, Merilee S., “Good Enough Governance Revisited.” Development Policy Review, Vol. 25, No. 5 (2007).

International Monetary Fund(IMF), Good Governance: The IMF's Role (Washington, D.C.: IMF, 2005).

Knack, Stephen and Philip Keefer, "Institutions and Economic Performance: Cross-Country Tests Using Alternative Institutional Measures.” Economics and Politics, Vol. 7 (1995).

OECD, Development Co-operation Report 2007 (Paris: OECD, 2007).

OECD, Development Co-operation Report 2010 (Paris: OECD, 2010b).

OECD, Final Report of the Ad Hoc Working Group on Participatory Development and Good Governance (Paris: OECD, 1997).

OECD, Governance, Taxation and Accountability: Issues and Practices (Paris: OECD, 2008).

OECD, Inside the DAC: A Guide to the OECD Development Assistance Committee 2009 2010 (Paris: OECD, 2010a).

OECD, Participatory Development and Good Governance (Paris: OECD, 1995).

OECD, Principles for Donor Action in Anti-corrupt (Paris: OECD, 2006b).

OECD, The DAC Guidelines: Poverty Reduction (Paris: OECD, 2001).

OECD, The Development Dimension: Integrating Human Rights into Development: Donor Approaches, Experiences and Challenges (Paris: OECD, 2006a).

Overseas Development Institute(ODI), Governance, Development and Aid Effectiveness: A Quick Guide to Complex Relationships (UK: ODI, 2006).

UNDP, Governance for Sustainable Human Development (New York: UNDP, 1997). 
United Nations Development Programme(UNDP), Human Development Report 2003. Millennium Development Goals: A Compact Among Nations to End Human Poverty (New York: Oxford University Press, 2003).

United Nations Economic and Social Commission for Asia and the Pacific (ESCAP) \& UNDP \& Asian Development Bank (ADB), Access to Basic Services for the Poor: The Importance of Good Governance (New York: United Nation, 2007).

World Bank, Governance Matters VIII: Aggregate and Individual Governance Indicators 1996 2008 (Washington D.C: The World Bank, 2009a).

World Bank, Sub-Saharan Africa: From Crisis to Sustainable Growth (Washington D.C: The World Bank, 1989).

World Bank, The World Bank's Country Policy and Institutional Assessment (Washington D.C: The World Bank, 2009b). 